\title{
Under the Ancestor's Eyes: Kinship, Status and Locality in Pre-Modern Korea. By Martina Deuchler. Cambridge, Mass: Harvard University Asia Center, 2015. xviii, 609 pp [ISBN: 9780674504301]
}

Adam Bohnet*

Martina Deuchler's Under Ancestors' Eyes: Kinship, Status and Locality in Pre-Modern Korea, is a vast and ambitious work that seeks to explore the development of kinship - and the persistent importance of kinship and inherited social status - in pre-modern Korea from the early Silla dynasty to 1894 . The bulk of the book, which is concerned with Andong and Namworn from the fifteenth century to the nineteenth, makes extensive use of documents from aristocratic sajok household of those areas to reconstruct the development of sajok status during the Chosorn period. She works with the ambitious goal of tracing a "native kinship ideology" that placed the social maintenance of aristocratic social status above court politics. As she writes in the conclusion: "The indigenous kinship ideology, with its celebration of status hierarchy and status exclusivity, ran like a red thread through Korea's history from early Silla to the late nineteenth century" (408).

The book is organized into five parts, each divided into several chapters. Part I, "Foundations" (15-76), explores the trajectory of a hereditary

* Associate Professor, Department of History, King's University College at the University of Western Ontario, Canada. 
elite between the early Silla to the Koryŏ-Chosŏn transition, as well as the role of Neo-Confucianism in transforming Korean society during the early Chosŏn. Part II, "Rebuilding the Countryside" (79-155), explores the development of communities of "localized elite descent groups" in the two southern communities of Andong in Kyŏngsang province and Namwŏn in Chŏlla. Part III, "Confucian learning and practice" (159-234), argues for the key role of Confucian teaching, learning and ritual practice in these two regions during the sixteenth century. It also outlines the emergence of key Confucian teachers, with an emphasis on Yi Hwang (15011570 , more often known by his sobriquet T'oegye) whose philosophical approach became dominant in the Andong region. Part IV, "Divisions and Bondings" (237-338), discusses the maturation of the lineage system in these two regions during the seventeenth and eighteenth centuries in the context of a growing rift between rural sajok and the capital elites who monopolized the bureaucracy. Part V, "Survival in a Changing World" (341-396), analyzes the persistence of lineage society despite the decline of slavery (which was finally abolished in 1894), the economic immiseration of many rural sajok, and increasing challenges to sajok from secondary status groups including sŏŏl (the descendants of sajok and their base concubines) and hyangni (village functionaries), and even from commoners.

From Part II onward, the book is structured as a social history of Andong and Namwŏn during the Chosŏn period, with a view to exploring broader social developments in Chosŏn as a whole. Perhaps it might even be better characterized as a history of Andong's sajok elite, for the bulk of the text, and the richest discussion, concerns Andong, with Namwŏn often seeming tagged on. This is especially true in Part II and Part III, although that may to some extent be attributed to the accident of survival, and to the fact that Andong suffered much less from the Imjin War than did Namwŏn. In Part II, chapters 4 (79-106) and 5 (107-131) which introduces the sajok of Andong and Namwŏn, are fairly well balanced. However, by my rough calculation, more than $70 \%$ of chapter 6 , "Consolidation of Localized Elites in Mid-Dynasty" (132-155), which explores the econom- 
ic foundations of the sixteenth-century elite, is concerned with Andong. By contrast, only about $9 \%$ of chapter 6 is exclusively concerned with Namwŏn. In Part III, chapter 7, "The Sajok Elites as Confucian Learners" (163-186), which explores the rise of Confucian learning among the sajok during the sixteenth century, spends $75 \%$ of its pages on the rise of the T'oegye school based in Andong, with the remaining few pages devoted to such Confucians of Chŏlla as Kim Inhu (1510-1560) and Yu Hŭich'un (1513-1577), and with one page on Cho Sik (1501-1572) of southern Kyŏngsang. Chapter 8, "Ritual Practice and Early Formation of Localized Elites" (185-207), is almost exclusively concerned with Andong, with only two sentences on page 199 referring to the likely development, on the basis of circumstantial evidence, of a similar phenomenon in Namwŏn. Similarly, Chapter 9, "Community Stratification and Local-Level Leadership" (208-234), which traces the development of Andong society during the sixteenth century up to the Imjin War (1592-1598), is about $80 \%$ concerned with Andong, with approximately two pages on Namwŏn.

Even in the later chapters, concerning periods when Namworn documents become more available, Andong overwhelmingly dominates the narrative. Part IV is a bit more balanced, with chapters 10 ("Center and Periphery," 245-265) and 11 ("The Maturation of the Lineage System," 266-303) alternating between Andong and Namwŏn, although even here key sections are primarily concerned with Andong cases. For instance, Andong monopolizes the discussion of rites to the ancestors (270-275), the role of munjung as kin-contracts (280-287), and the maturation of "localized lineage organizations" (287-289). The following chapter 12, "Learning and Politics" (304-344), explores the continuation of the Namin faction and T'oegye school in opposition to the capital elites, and is thus almost exclusively concerned with Andong, except for approximately two pages on Namwŏn. This Andong-orientation continues in Part V. Chapter 13, "Transformation within Stability" (345-369), is fairly well-balanced between the two regions. Even here the Andong bias is apparent, for instance, in the section on "Memorials to Ancestors: Shrine Construction and Munjip Compilation" (p. 358-363), in which, except for 
one brief paragraph on Namwŏn, only examples from Andong are discussed. At the end of this section, Deuchler concludes that, "The Andong and Namwŏn sajok, though far removed from the center, were thus never idle." In fact, this reviewer must protest, on the basis of the evidence provided by Deuchler, the sajok of Namwŏn may well have spent their days largely mired in disgraceful sloth. Finally, Chapter 14, "The End of Sajok Supremacy" (370-396), is an absolutely vital chapter which explores challenges to the sajok elites from hyangni, sŏŏl, and commoners, and the decline of slavery. Yet it also overwhelmingly relies on Andong for specific examples, with a few scattered and perfunctory references to Namwŏn.

This overwhelming focus on Andong is in many ways the book's great strength. The rich materials concerning the social history of northern Kyŏngsang province in this book are extremely useful, and I have already made considerable use of them in the classroom. I note, as examples, the detailed discussion of the treatment of base secondary sons in sixteenthcentury Andong (126-131), the exploration of the philosopher T'oegye's approach to slave-holding (140-141), and the analysis of the relationship between the Andong Local Bureau and the state (218-223) as sections that provide especially rich and lively information, that allow the reader to link social, political and intellectual developments, and see how a range of interlocking factors transformed the lives of individuals. Deuchler shows us, for instance, how the family of a base-born secondary son in sixteenth century Andong might debate and argue about the secondary son's status in the context of the economic, social and political circumstances of the time. Chapter 12's overwhelming focus on Andong, as well, provides an informative exploration of the manner in which private Confucian academies became centers of resistance by the Namin faction against the capital elite. The capital elites, of course, were generally members of the Sorin faction, or later, of the Noron sub-faction, and pursued a different brand of neo-Confucianism.

One might almost describe chapter 12 as "political history of the late Chosŏn, viewed through Andong eyes." The Musin uprising of 1728, is 
almost entirely discussed from the point of the Andong region. In part this is reasonable, as the Musin uprising was much less successful in Chŏlla than it was in Kyŏngsang and Ch'ungch'ŏng provinces. But it did not leave Chŏlla unscathed, and Namwŏn itself, though a target of attack, successfully resisted the rebels; indeed, many Namwŏn sajok were honored for their role in the resistance. ${ }^{1}$ It would thus seem that Namworn should also have been part of this discussion. Elsewhere, at times Deuchler expresses some distinctly Andong-centric prejudices. Consider her description of Chŏng Inhong (1535-1623), the intellectual leading light of the Taebuk faction, who sought to expel the tablets of two philosophers admired by the Namin, namely T'oegye and Yi Önjŏk, from the Confucian Temple (Munmyo) in the capital. Deuchler describes Chŏng as "an ideologue," his actions as a "daring assault by a splinter Pugin group," whose "malicious advance" was blocked only by a "concerted Confucian effort" from sajok in Kyŏngsang province. However, "a bitterly resentful Chŏng took quick revenge" through a "trumped-up charge of conspiracy" (314). For the most part, I appreciate having such a clearly Naminoriented view of late Chosŏn politics as this is otherwise largely lacking in English. The language, however, does seem somewhat over-the-top for a work of twenty-first century scholarship.

Much though I value this overweighting of Andong evidence, it does weaken the argument of the book. In a response to another reviewer, Deuchler asserted that the interesting "convergences in social organization and Confucian culture [between Andong and Namwŏn], despite their adherence to divergent scholarly orientations," suggest that one might well be able to apply its discoveries to other regions of Korea. ${ }^{2}$ While this is certainly possible, this reviewer is left with many doubts concern-

1 Ko Suyŏn, “1728nyŏn Honam musillan ŭi chŏn'gae yangsang kwa pallan'gun ŭ sŏnggyŏk," Yŏksa wa tamnon 60 (December 2011): 31-72.

2 Martina Deuchler, "Reply to "The Dynamics of Elite Domination in Early Modern Korea” by Javier Cha," Sungkyun Journal of East Asian Studies 17, no. 2 (October 2017), 263. 
ing these convergences, considering how often Namwŏn is not really part of the discussion. The sajok of the Andong region were considered, even during the Chosŏn period, as proudly independent of the center and as unusually successful in maintaining their local supremacy. Because the Andong region's dominant Namin faction largely lost its links to the capital during the eighteenth century, and because the T'oegye school had always deemphasized political involvement, the Andong region is extraordinarily well-suited to Deuchler's argument that sajok supremacy was primarily driven by regional social factors. How might the argument have changed if the lack of enthusiasm for the Musin uprising in Chŏlla had been taken more into account? What might we see with a detailed analysis of Chŏlla's Neo-Confucian traditions? Deuchler does note that Chŏlla's Confucianism was different, that Chŏlla's Confucians were philosophically more eclectic and generally linked with the dominant Sŏin faction of the capital. However, she does not provide a detailed account of the emergence of Neo-Confucianism in Chŏlla that led to the rise of such thinkers such as Kim Inhu or Yu Hŭich'un in the sixteenth century, although, in fact, a fair amount has been written on this subject. ${ }^{3}$ She also does not engage in a discussion of the politics and intellectual lineages of Confucian schools in Namworn during the late Chosŏn that is in any way comparable to her discussion of the Confucian academies of Andong. Because Chŏlla intellectual traditions were less resistant to the dominant Sŏin faction, this surely would have left us with a less stark divide between the sajok descent-groups of the regions and the politics of the capital. As I am not convinced that she has revealed convergences between both Namwŏn and Andong, I cannot but doubt the applicability of her work to Chosŏn as a whole.

I am also doubtful of her attempts to make broader claims about "premodern Korea." Her discussion of the Silla period (18-21), ${ }^{4}$ for instance,

3 For this subject, see Ko Yŏngjin, Honam sarim ŭi hangmaek kwa sasang (Seoul: Hyean, 2007).

4 Problems with this section have also been discussed by earlier reviewers. See Sem 
is extremely brief, and not only involves no independent analysis of primary sources (whether later histories, or archaeological and epigraphic sources), it does not even distinguish her ideas from those of other scholars, as her citations simply list a series of great names, without any attempt to show how her argument differs. Moreover, she makes no clear distinction, as is standard for the study of early Korea, between early, middle and late Silla. Certainly, there is insufficient detail to observe a "native kinship ideology" during the Silla period.

Her discussion of late Koryŏ-early Chosŏn is much better, and more extensive. I don't find it entirely satisfactory, though. Perhaps inevitably in a work of such a scale, she takes some dubious positions. A fairly minor example, for instance, is her discussion of the late Koryŏ monk/administrator Sin Ton (1322-1371), a bête-noire of much later historiography. On page 43 , she accepts at face value the claim made in the Koryǒsa (the official dynastic history of the Koryŏ dynasty) that Sin Ton, and not King Kongmin, sired King U (r. 1374-1388). Considering that the founder of Chosŏn, Yi Sŏnggye (1335-1408), overthrew King U before taking control of the state, the claim that King $U$ was not of royal descent would seem to be obviously early Chosŏn propaganda. Indeed, it was clearly identified as such by eighteenth-century Chosŏn historians, including the great An Chŏngbok (1712-1791). ${ }^{5}$

Rather more problematic to this reviewer was her discussion of the Neo-Confucianism of the founding elites of the early Chosŏn (64-76). An earlier perspective on the founding of the Chosŏn period, reflected in an edited volume by Theodore de Bary, Jr. and Jahyun Kim Haboush to

Vermeersch, review of Under the Ancestors' Eyes. Kinship, Status, and Locality in Premodern Korea, by Martina Deuchler, Seoul Journal of Korean Studies 32, no. 2 (2018): 265-268, and Javier Cha, "The Dynamics of Elite Domination in Early Modern Korea," Sungkyun Journal of East Asian Studies 17, no. 1 (2017): 93-109.

5 Jeong Ho-hun, "Deconstructing the Official History of Koryŏ in Late Chosŏn - The Discovery of the Un'goksisa and the Refutation of the Theory that Sin Ton Sired Kings U and Ch'ang," Seoul Journal of Korean Studies 26, no. 2 (December 2013): 335-360. 
which Deuchler contributed, understood the founding fathers of the new dynasty to be ideologically convinced Neo-Confucians. ${ }^{6}$ This view has since been questioned, including, in English, by John B. Duncan, who pointed out that the founders of the early Chosŏn were doctrinally quite eclectic, and generally combined Zhu Xi (1130-1200)'s NeoConfucianism with the Old Text (komun) school of Han Yu (768-824), Ouyang Xiu (1007-1072) and Su Shi (1037-1101). Zhu Xi's Neo Confucian orthodoxy, Duncan argues, did not dominate until the sixteenthcentury. ${ }^{7}$ Duncan himself was building on the work of Tillman and Boll, who argue that the focus on the Zhu Xi school had obscured the considerable intellectual diversity of the Song period. ${ }^{8}$

Deuchler's attempt to restore Neo-Confucianism to the Koryŏ-Choson transition is not entirely convincing, and many of her key arguments lack a strong basis in evidence. For instance, part of Duncan's evidence had been that Yi Chehyŏn (1288-1367), often seen as the founder of Tohak (learning of the way) of the Koryŏ-Chosŏn transition, was described in the Koryŏsa as one who "did not enjoy sŏngnihak (the learning of nature and principle)," a term used for the metaphysical aspects of Zhu Xi's Neo-Confucianism. Deuchler criticizes Duncan's position in a lengthy footnote (454, footnote 17), in which she argues that Duncan had erred in reading this at face-value without considering the context, which was that of Yi Chehyŏn's 's conflict with Sin Ton. Furthermore, she argues that because this section of the biography was derived from Yi Chehyŏn's tomb inscription, but this line was not in the tomb inscription, the line must have been "added later." She declares herself perplexed that "such a

6 William Theodore De Bary and JaHyun Kim Haboush, The Rise of NeoConfucianism in Korea (New York: Columbia University Press, 1985).

7 John B. Duncan, The Origins of the Chosŏn Dynasty (Seattle: University of Washington Press, 2000).

8 Hoyt Cleveland Tillman, Confucian Discourse and Chu Hsi's Ascendancy (Honolulu: University of Hawaii Press, 1992); Peter K. Bol, This Culture of Ours: Intellectual Transitions in T'ang and Sung China (Stanford: Stanford University Press; 1992). 
misleading statement" had been included by the compilers of the final edition of the Koryǒsa in 1451. Finally, she expresses regret that there has not as yet been a proper biography of Yi Chehyŏn.

I have quite a number of problems with this footnote. First, I see no reason why this line should be read in the context of Yi Chehyŏn's 's conflict with Sin Ton. The line appears as part of a general summing up of Yi Chehyŏn's career, after a generally chronological overview, and before a discussion of Yi Chehyŏn's 's publications. It appears after the discussion of Sin Ton for the simple reason that Yi Chehyŏn's career and life came to an end while Sin Ton was still in ascendant. If one consults the digital version provided by http://db.history.go.kr/KOREA/, the line does indeed fall in the same paragraph as Yi Chehyŏn's conflict with Sin Ton, but that paragraph division is not of course present in the original printed text. There is also no reason at all to assume that the line is any younger than the tomb inscription - and both it and the information derived from the tomb inscription, of course, may have been added to the Koryǒsa biography at exactly the same time. I share her enthusiasm for a wellcontextualized biography of Yi Chehyŏn, but I do hope that future biographers take the phrase "did not enjoy sŏngnihak" seriously and will attempt to understand why the editors of the Koryossa included it, as opposed to simply dismissing it as misleading. In any case, arguments of this sort have, in anything, made me more convinced that the founding elites of the early Chosŏn should not be understood as having been inspired by Neo-Confucian orthodoxy.

A further challenge with this book is that she at no point defines her key terms (which she often places in italics): the social, the political and the economic. ${ }^{9}$ Of course, it would be quite unexceptional to describe kinship as socially-constructed or socially-manipulated, but those who use the phrase "socially-constructed" generally are not contrasting the social

9 Or for that matter, "ideology." See Jisoo M. Kim, review of Under the Ancestors" Eyes. Kinship, Status, and Locality in Premodern Korea, by Martina Deuchler, Asian Studies Review 41, no. 2 (April 2017): 265-268. 
with politics and economics, as Deuchler does here. Her introduction provides little help. She describes most earlier explorations of pre-modern Korean elites as having been concerned with political and institutional changes, or with economic foundations, with those few works that discuss the "social basis of elite power" being concerned with "class analysis or conflicts of interest between social groupings" (1). Conflict between social groupings is rather key to how a great many, perhaps most, social historians would understand society, but Deuchler never defines what she means by the social, or how she draws the lines between it, and economics and politics.

Generally, but not always, the social seems to be simply that which pertains to rural sajok and to self-generated tools of status-maintenance, as opposed to such tools of the court and capital as examinations and official position. In her preface (xiv) she states that "Korean society's basic unit" was the "descent group." This cannot be true, since the majority of the population of pre-modern Korea was not a member of a proper descent-group. Obviously, petty functionaries in the capital were also part of society, as were merchants in Kaesŏng, impoverished commoners in Hamgyŏng, and fugitive slaves in off-shore islands in Chŏlla, while Andong sajok had their own politics. Generally Deuchler defines the social against exam-passing and office-holding, which belong clearly to the province of the political (for instance, 405-406), but in her discussion of the conflict between the sejok elite and the parvenu kwornmun during the late Koryŏ (36-38), the sejok are described as maintaining the social, substantially defined by exams and office-holding, against the political, referring to those kwŏnmun who entered politics through connections. Perhaps these are all reasonable decisions on her part, but the lack of clear definitions makes it hard to judge.

In a number of cases, the terms the social, the political and the economic seem forced and out of step with the sources that she provides. I note, for instance, page 125, when, after a discussion of the shift away from uxorilocal marriage and the increased tendency for sajok decent-groups to make close marital bounds with other families in the region, she quotes 
the advice of Kwŏn Yang (1628-1697) that, "generally, regardless of whether it is for the marriage partner of a daughter or a son, first investigate the family background (munbŏl), and then the family's moral principles (kabóp)." Her comment on this quotation is that "marriage criteria" had "clearly shifted from the economic to the social, as a verifiable ancestral background remained the surest touchstone against which sajok status could be vetted." However, although she does reveal a wide range of changes in marital practices, the sources that she provides do not show any declining interest in the economic circumstances of a marriage partner. Needless to say, what one scholar thought about marriage tells us what he believed about how people should act, but it does not tell us what other people actually did.

In chapter 14 , she seems to shift, quite unaccountably to asserting the overwhelming importance of the political against the social. After discussing the decline of slavery in late Chosŏn, partly driven by the changing economics of slavery, and partly driven by various acts of resistance (notably including flight) by the slaves, she makes a puzzling statement: "Although Korean historiography usually depicts the nonelite as the principal actors who set off the dynamics of social change, shaking late Chosŏn society from the bottom up, the historic obliteration of the traditional status system, however revolutionary in its consequences, was not achieved by rebellious elements from below, but was set in motion, paradoxically, from the top - by royal fiat" (393). This she follows with a series of royal pronouncements by monarchs, and critical statements by late Chosŏn intellectuals concerning slavery, primarily based on scholarship by James Palais.

I find this passage somewhat puzzling. First, Korean scholars certainly do discuss the role of legislation in the decline of slavery, and criticism of slavery expressed by some late Chosŏn intellectuals - I read about all of this in Korean as an MA student at Kangwŏn National University in the late 1990s. Second, it is of course quite unexceptional (not paradoxical at all) that the legislation limiting slavery would come "from the top." That is where laws are passed, everywhere. Haiti, after all, is unique or nearly 
unique as an example of a society in which slavery was destroyed through revolution. The relation between abolition and slave resistance in the case of the Atlantic Slave Trade is, to be sure, controversial and subject to debate, but generally scholars do not see this as a matter of either-or. ${ }^{10}$ On the one hand, slavery may survive extra-legally, despite abolition, where the social and economic conditions warrant, while on the other hand, resistance to slavery takes many forms short of open rebellion, including such relatively passive forms as shirking work, and more active forms such as suicide, flight, or violence against masters, all of which can raise the cost of slavery to the point that it becomes economically unfeasible. Indeed, Deuchler provides numerous examples of just such minor but effective resistance in the immediately preceding section, as indeed one would expect in a book concerned to argue above all for the importance of the social. This makes her decision to then argue the opposite case somewhat surprising.

In short, this is a large and complicated work. I can without reservations recommend it as a fascinating and highly informative history of the Andong region that blends the political, social, economic and ideological. Later scholars will benefit enormously from it. The broader argument I cannot support quite as fully, but later scholars will surely be inspired by the audacity of her attempt to create a new narrative of Korean history, even if this narrative passed somewhat beyond the evidence that she provides. For this, all scholars of the Chosŏn period owe her considerable thanks.

10 There is an extensive debate, but I refer the reader to two books, namely Seymour Drescher and Pieter C. Emmer, eds., Who Abolished Slavery? Slave Revolts and Abolitionism - a Debate with João Pedro Marques (New York: Berghahn Books, 2010) and Derek R. Peterson, ed., Abolitionism and Imperialism in Britain, Africa, and the Atlantic (Athens, Ohio: Ohio University Press. 2010). 